\title{
Bioprospective screening of ricinodendron heudelotii seeds
}

\begin{abstract}
A plant becomes a medicinal plant only when its biological activities has been ethnobotanically reported and scientifically established. The plant Ricinodendron heudelotii has been used traditionally for various disease treatments. The qualitative and quantitative analyses of the seed extract were carried out. The result of the analysis revealed an appreciable amount of phytochemicals such as Tannins, Saponins, Flavonoids, Alkaloids, and Phenols. Minute amount of phytate, oxalates were present. Also present were carotenoids and anthraquinones. These phytochemicals have been reported to have various biological characteristics such as anti-oxidant, anti-inflammatory and anti-carcinogenic properties. This result therefore suggests the potency of Ricinodendron heudelotii for therapeutic and pharmaceutical uses.
\end{abstract}

Keywords: ricinodendron heudelotii, phytochemicals, seed extracts, therapeutic, pharmaceutical
Volume 3 Issue 7 - 2016

\author{
Odinga Tamuno Boma, Worlu Wodo QE, \\ Deekae S \\ 'Department of Biochemistry, Rivers state university of science \\ and technology, Nigeria \\ ${ }^{2}$ Department of Chemistry, Rivers state university of science \\ and technology, Nigeria
}

Correspondence: Odinga Tamuno Boma, Department of Biochemistry, Rivers state university of science and technology, Port Harcourt, Nigeria, Email bomaodinga@gmail.com

Received: November 16, 2016 | Published: December 29, 2016

\section{Introduction}

The plant Ricinodendron heudelotii commonly called Njangsa is an oily seed tree that has long been used as a medicinal plant. Its uses includes: an antidote against poison, because the extract of the bark are said to contain lupeol, to cure various diseases such as cough, malaria, yellow fever, stomach pain, rheumatism. Other characteristics of the plant are its aphrodisiac and anti-Inflammatory properties. It has also been used for treatment of infertility and menstrual pain.

According to World Health Organization, ${ }^{1}$ a medicinal plant is any plant which contains substances that can be used for the therapeutic purpose or substances which are precursors for the synthesis. A plant becomes a medicinal plant only when its biological activities has been ethnobotanically reported or scientifically established. ${ }^{2,3}$

In contrast to synthetic conventional pharmaceuticals, many medicinal plants exert their beneficial effects through the additive or synergistic action of several chemical compounds acting at single or multiple target sites associated with a physiological process, ${ }^{4}$ Hence the need to screen the seed of Ricinodendron heudelotii for the presence and concentration of the secondary metabolites (phytochemicals), as the seed is majorly used in preparing various dishes.

Phytochemicals are chemical compound that occur naturally in plant, provide the plant with it various characteristics such as colour, flavor, odor and other organoleptic properties .These secondary metabolites are medicinal and can also be obtained from various anatomical structures of plants ${ }^{2,5}$ reported that most of the phytochemicals are produced through biosynthesis in the metabolic pathway $^{6,7}$ also reported that the various phytochemicals have the following potentials:

a. Carotenoids: May inhibit cancer cell growth, act as an antioxidant and improve immune response.

b. Flavonoids (anthocyanins): May inhibit inflammation and tumour growth, also aid immunity and boost production of detoxifying enzymes in the body.

c. Inositol (phytic acid): May retard cell growth and work as antioxidants. d. Isoflavones: May inhibit tumour growth, limit production of cancer related hormones and generally work as antioxidants.

e. Isothiocyanates: may induce detoxification of carcinogens, block tumour growth and work as antioxidants.

f. Polyphenols: may prevent cancer formation, inflammation and work as antioxidants.

g. Terpenes: may protect cells from becoming cancerous, slow cancer cell growth, strengthen immune function, limit production of cancer related hormones, fight viruses, and work as antioxidants.

h. Indoles and glucosinolates: may induce detoxification of carcinogens, limit production of cancer related hormones, block carcinogens and prevent tumour growth.

This study therefore screens for the presence (qualitative) and concentration (quantitative) phytochemical constituents of the extract of the dried Ricinodendron heudelotii seed, aimed at enhancing the therapeutic value and its use in pharmaceutical industries.

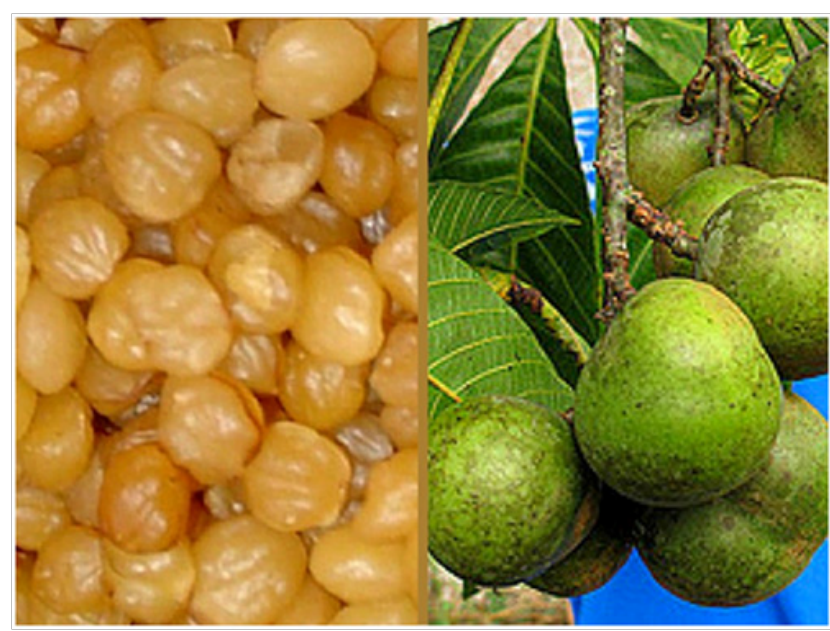

Figure I Ricinodendron heudelotii dried seeds and fruits. 


\section{Materials and methods}

\section{Collection and identification of the plant sample}

The dried seeds of Ricinodendron heudelotii were collected from a local food spice market in Port Harcourt, Rivers state, Nigeria. The sample was identified by the department of Plant Science and Biotechnology, University of Port Harcourt, Nigeria. The seed was ground into fine powder using a manual grinding machine in the Department of Chemistry laboratory, Rivers state university of science and technology, Nigeria.

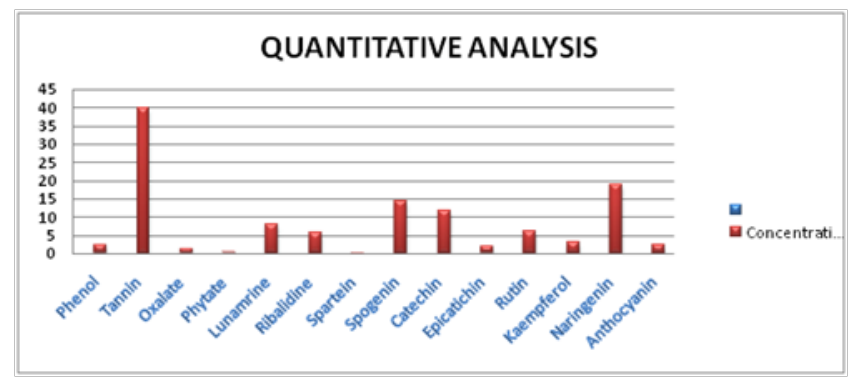

Figure 2 Quantitative phytochemical analysis of ethanolic seed extract of Ricinodendron heudelotii showing the concentration of the various phytochemical component.

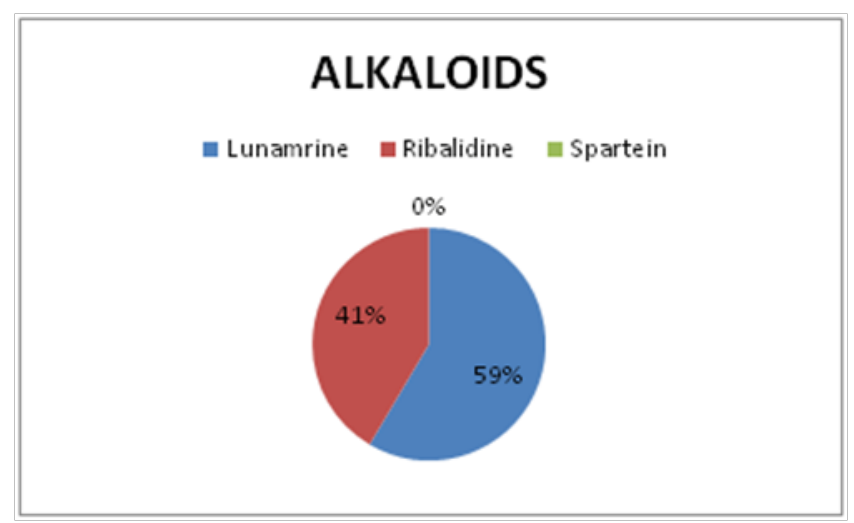

Figure 3 Percentage concentration of sub-class of Alkaloids of ethanolic seed extract of Ricinodendron heudelotii.

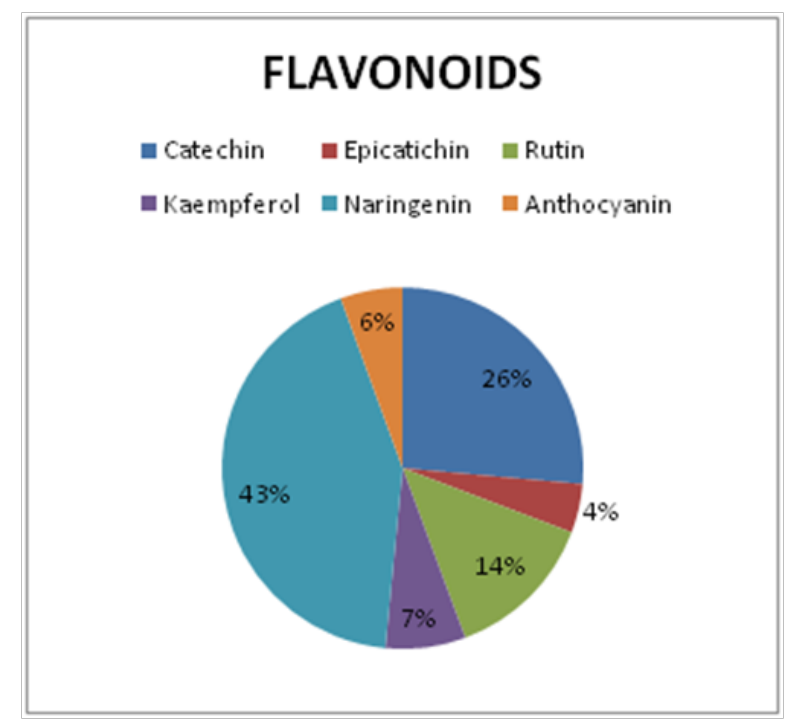

Figure 4 Percentage concentration of sub-class of Flavonoid Of ethanolic seed extract of Ricinodendron heudelotii.

\section{Quantitative (concentration) screening}

$1 \mathrm{~g}$ of the sample powder was weighed and transferred into a test tube. $15 \mathrm{ml}$ ethanol and $10 \mathrm{ml}$ of $50 \% \mathrm{~m} / \mathrm{v}$ potassium hydroxide was added. The test tube was allowed to heat in a water bath at $60 \mathrm{oC}$ for $60 \mathrm{mins}$. After the reaction time, the reaction product contained in the test tube was transferred to a separatory funnel. The tube was thoroughly washed with $20 \mathrm{ml}$ ethanol, $10 \mathrm{ml}$ cold water, $10 \mathrm{ml}$ hot water and $3 \mathrm{ml}$ hexane, which was all transferred to the funnel. The solution was dried with anhydrous sodium sulfate and the solvent was evaporated. The sample was solubilized in $1000 \mu 1$ of pyridine of which $200 \mu 1$ was transferred to a vial for analysis.

\section{Quantification by gas chromatography flame ionization detector (GC-FID)}

The analysis for phytochemical was performed on a BUCK M910 Gas chromatography equipped with a flame ionization detector. A RESTEK 15 meter MXT- 1 column $(15 \mathrm{~m} \times 250 \mathrm{um} \times 0.15 \mathrm{um})$ was used. The injector temperature was $280^{\circ} \mathrm{C}$ with splitless injection of $2 \mu 1$ of samples and a linear velocity of $3^{\circ} \mathrm{C}$ ms-1, helium 5.0pa.S was the carrier gas with a flow rate of $40 \mathrm{mlmin}-1$. The oven operated initially at $200^{\circ} \mathrm{C}$, it was heated at $330^{\circ} \mathrm{C}$ at a rate of $30 \mathrm{c} \mathrm{min}-1$ and was kept at this temperature for $5 \mathrm{mins}$. The detector operated at a temperature of $320^{\circ} \mathrm{C}$.

Phytochemicals were determined by the ratio between the area and mass of internal standard and the area of the identified phytochemicals. The concentration of the different phytochemicals is expressed in ug/g.

\section{Qualitative (presence) screening Method of extraction}

Chemical tests were carried out on the aqueous extract of the powdered sample of the Ricinodendron heudelotii using standard procedures to identify the constituents. ${ }^{8}$

\section{Test for tannins}

$0.5 \mathrm{~g}$ of the dried powder sample was boiled in $20 \mathrm{ml}$ of water in a test tube and filtered. 3 drops $0.1 \%$ ferric chloride was added and observed for brownish green or blue black coloration.

\section{Test for saponins}

$1 \mathrm{~g}$ of powdered sample was separately boiled with $10 \mathrm{ml}$ of distilled water in a beaker for 10minutes. The mixture was filtered while hot and allowed to cool. The following tests were then carried out:

Frothing test: $2.5 \mathrm{ml}$ of filtrate was diluted to $10 \mathrm{ml}$ with distilled water and shaken vigorously for 2 minutes; Frothing indicated the presence of saponin in the filtrate.

Emulsion test: 2 drops of olive oil was added to the solution obtained from diluting $2.5 \mathrm{ml}$ filtrate to $10 \mathrm{ml}$ with distilled water (above), shaken vigorously for a few minutes Formation of a fairly stable emulsion indicated the presence of saponins.

\section{Test for phlobatannins}

$5 \mathrm{ml}$ aqueous extract of sample was boiled with $1 \%$ aqueous hydrochloric acid. Deposition of red precipitate was taken as evidence for phlobatannins.

\section{Test for terpenoids}

$5 \mathrm{ml}$ of aqueous extract of sample seed was added in $2 \mathrm{ml}$ of chloroform. $3 \mathrm{ml}$ of concentrated $\mathrm{H} 2 \mathrm{SO} 4$ was then added to form a 
layer. A reddish brown precipitate coloration at the interface formed indicated the presence of terpenoids.

Table I Quantitative phytochemical analysis of ricinodendron heudelotii seed

\begin{tabular}{lll}
\hline Component & Sub-class & Concentration $\boldsymbol{\mu g} / \mathbf{g}$ \\
\hline Phenol & & 2.2357 \\
\hline Tannin & 39.9463 \\
\hline Oxalate & 1.1581 \\
\hline Phytate & 0.2946 \\
\hline Alkaloid & Lumamarine & 7.9079 \\
\hline & Ribalidine & 5.608 \\
\hline & Spartein & 0.0002 \\
\hline Saponin & Sapogenin & 14.2632 \\
\hline Flavonoid & Catechin & 11.5693 \\
\hline & Epicatechin & 1.9145 \\
\hline & Rutin & 5.9573 \\
\hline & Kaempferol & 3.1418 \\
\hline & Naringenin & 18.7939 \\
\hline & Anthocyanin & 2.4412
\end{tabular}

Table 2 Qualitative phytochemical analysis of ricinodendron heudelotii seeds

\begin{tabular}{ll}
\hline Component & Result \\
\hline Tannin & $+\mathrm{ve}$ \\
Phlobatannins & $-\mathrm{ve}$ \\
Flavonoid & $+\mathrm{ve}$ \\
Alkaloid & $+\mathrm{ve}$ \\
Cardiac glycoside & $+\mathrm{ve}$ \\
Terpenoid & $+\mathrm{ve}$ \\
Saponin frothing & $+\mathrm{ve}$ \\
Saponin emulsifying & $+\mathrm{ve}$ \\
Combined anthraquinone & $+\mathrm{ve}$ \\
Free Anthraquinone & $-\mathrm{ve}$ \\
Carotenoid & $+\mathrm{ve}$ \\
Reducing compound & $-\mathrm{ve}$
\end{tabular}

\section{Test for flavonoids}

$1 \mathrm{~g}$ of the powder sample was heated with $10 \mathrm{ml}$ of distilled water for 5 minutes and filtered while hot. Few drops of $20 \%$ sodium hydroxide solution were added to $1 \mathrm{ml}$ of the cooled filtrate. A change to yellow colour which on addition of acid changed to colorless solution depicted the presence of flavonoids.

\section{Test for cardiac glycosides}

$5 \mathrm{ml}$ of aqueous extract was treated with $2 \mathrm{ml}$ of glacial acetic acid containing one drop of ferric chloride solution. This was underplayed with $1 \mathrm{ml}$ of concentrated sulphuric acid. A brown ring at the interface indicated the deoxy sugar characteristics of cardenolides.

\section{Test for combined anthraquinones}

$1 \mathrm{~g}$ of powdered sample was boiled with $2 \mathrm{ml}$ of $10 \%$ hydrochloric acid for 5 mins. The mixture was filtered while hot and filtrate was allowed to cool. The cooled filtrate was partitioned against equal volume of chloroform and the chloroform layer was transferred into a clean dry test tube using a clean pipette. Equal volume of $10 \%$ ammonia solution was added into the chloroform layer, shaken and allowed to separate. The separated aqueous layer was observed for any colour change. Light rose pink colour showed the presence of combined anthraquionone.

\section{Test for free anthraquinones}

$5 \mathrm{ml}$ of chloroform was added to $0.5 \mathrm{~g}$ of the powdered sample. The resulting mixture was shaken for $5 \mathrm{mins}$ after which it was filtered.
The filtrate was then shaken with equal volume of $10 \%$ ammonia solution. The presence of a bright pink colour in the aqueous layer indicated the presence of free anthraquinones.

\section{Test for carotenoids}

$1 \mathrm{~g}$ of powdered sample was extracted with $10 \mathrm{ml}$ of chloroform in a test tube, filtered and $85 \%$ sulphuric acid was added. A blue colour at the interface showed the presence of carotenoids.

\section{Test for reducing compounds}

To $1 \mathrm{~g}$ of sample powder, $10 \mathrm{ml}$ distilled water was added. The mixture was allowed to boil for 5minutes, filtered while hot and the cooled filtrate made alkaline to litmus paper with $20 \%$ sodium hydroxide solution. The resulting solution was boiled with an equal volume of Benedict qualitative solution on a water bath. The formation of a brick red precipitate depicted the presence of reducing compound

\section{Test for alkaloids}

$\mathrm{Ig}$ of powdered sample was boiled with $2 \mathrm{ml}$ distilled water and $10 \mathrm{ml}(10 \%)$ hydrochloric acid on water bath and filtered. The $\mathrm{pH}$ of the filtrate was adjusted with ammonia to 10 . The following reagents were added separately to about $0.5 \mathrm{ml}$ of the filtrate in a different test tube and observed:

a. $10 \%$ tannic solution $-1 \mathrm{ml}$ tannic solution, formation of precipitate indicates presence of alkaloid.

b. Mayer's reagent (Potassium mercuric iodide solution). $1 \mathrm{ml}$ Mayer's reagent. Turbidity indicates the presence of alkaloid (Figure 2-4) (Table $1 \& 2$ ).

\section{Discussion}

The results obtained from the qualitative and quantitative phytochemical analysis reveals that tannin was present with the highest concentration. ${ }^{9}$ Reported that tannins has a natural defense mechanism against microbial infection, exert other physiological effects such as reduce blood pressure, decrease serum lipid level, produce liver necrosis, accelerate blood clotting and modulate immune responses. Carotenoids were also present in the seed. Carotenoids have been reported to neutralize free radicals that cause cell damage. ${ }^{2}$ The seed of the plant Ricinodendron heudelotii was found to contain phenolic compounds. Plants containing phenolic compounds possess antioxidant and anti-inflammatory properties.

Alkaloids and flavonoids were seen in appreciable concentration in the seed extract. Their content in plant materials have severally been reported to be a major anti-oxidant, anti-inflammatory and analgesic active principle. Alkaloid has widely been used medicinally as antiarrhythmic, anticholinergic, stimulant, analgesic, antimalarial and antihypertensive. ${ }^{10}$

The concentration of Saponin was appreciable $(14.2632)^{11}$ reported saponins to be included in the formulations used in the treatment of wounds, cough, asthma, hay fever and generally as antimicrobial and antiviral application. Saponins have also been used as adjuvants in vaccines to stimulate the Thi immune response and production of cytotoxic T- Lymphocytes against exogenous antigens. ${ }^{11}$

The low concentration of oxalate may be related to the fact that low amount of oxalate is needed by the body as too much of it may pose a risk of kidney stone. ${ }^{12}$ Also Phytate has been reported to have antioxidative properties and anti cancerogenic activities. ${ }^{13}$ The result of the analysis indicated the absence of Phlobatannins, 
free anthraquinone and reducing compounds. The presence of these phytochemicals in the plant Ricinodendron heudelotii suggests its potential therapeutically and its use in pharmaceutical industries. ${ }^{14-19}$

\section{Conclusion}

The plant Ricinodendron heudelotii has been used traditionally for the treatment of various diseases and sickness. The phytochemical screening of the seed of this plant has revealed the phytochemical constituent of the plant, hence suggesting its curative potency for various diseases and as such, its potential use therapeutically and in the pharmaceutical industries.

\section{Acknowledgments}

None.

\section{Conflicts of interest}

Author declares there are no conflicts of interest.

\section{Funding}

None.

\section{References}

1. WHO. Trace elements in human health and nutrition. World Health Organisation, Switzerland. 2008. p.1-361.

2. Dinkova-kostova AT. Phytochemicals as protectors against ultraviolet radiation: versatility of effects and mechanisms. Planta med. 2008;74(13):1548-1559.

3. Muazu J, Kaita AH. A Review of traditional plants used in treatment of epilepsy among the Hausa/Fulani tribes of northern Nigeria. Afr J Tradit Complement Altern Med. 2008; 5(4):337-340.

4. Okwu DE, Josiah C. Evaluation of chemical compositions of two Nigerian Medicinal Plants. Africa Journal of Biotechnology. 2006;5(4):357-361.

5. Akinpelu DA, Onakoya TM. Antimicrobial activities of medicinal plants used in folklore remedies in South-western. African Journal of Biotechnol. 2006; 5(11):1078-1081.
6. http://www.cancer.org/docroot/ETO/content/ETO3XPhytochemicals. asp?sitearea $=$ ETO

7. http://www.americanheart.org/presenter.jhtml?identifier $=4722$

8. Olaleye MT. Cytotoxicity and antibacterial activity of Methanolic extract of Hibiscus Sabdanffa. Journal of Medicinal Plants Research. 2007;1(1):009-013.

9. Muthu C, Ayyanar M, Raja N, et al. Medicinal plants used by Traditional healers in Kancheepuram District of Tamil Nadu, India. $J$ Ethnobiol Ethnomed. 2006;2:43.

10. Jeruto P, Mutai C, Catherine L, et al. Phytochemical constituents of some medicinal plant used by the nandis of south nandi district, Kenya. Journal of Animal and Plant Sciences. 2011;9(3):1201-1210.

11. Akinjogunla OJ, Yah CS, Eghafona NO, et al. Antibacterial activity of leave extracts of Nymphaea lotus(Nymphaeaceae) on methicillin resistant staphylococcus aureus(MRSA) and vancomycin resistant staphylococcus aureus(VRSA) isolated from clinical samples. Annals of biological research. 2010;1(2):174-184.

12. Coe FL, Evan A, Worcester E. Kidney stone diseases. J Clin Invest. 2005;115(10):2598-2608.

13. Schlemmer U, Frolich W, Prieto RM, et al. Molecular Nutrition \& Food Research. 2009;53(3):S330-S375.

14. Sofowora. Research on Medicinal plants and traditional medicine in Africa. J Altern Complement Med. 2008;2(3):365-372.

15. Manske RHF. The Alkaloids, chemistry and physiology. The Alkaloids: Chemistry and Physiology. 1965;8:673-678.

16. Chung KT, Wong TY, Wei CI, et al. Tannins and Human Health: A Review. Critical Reviews in Food Science and Nutritio. 1998;38(6):421-464.

17. Arts IC, Hollmans. Polyphenols and disease risk in epidemiologic studies. American journal of clinical nutrition. 2005;81(1):317S-325S.

18. Ayoola GA, Coker HAB, Adesegun SA, et al. Phytochemical screening and antioxidant activities of some selected medicinal plants used for malaria therapy in southwestern Nigeria. Tropical Journal of Pharmaceutical Research. 2008;7(3):1019-1024.

19. Abhilasha S, Kuntal K. Analysis of phytochemical constituents and Pharmacological properties of Abrus precatorius 1. International Journal of Pharma and Bio Sciences. 2013;4(1):91-101. 